A N N A L E S

UNIVERSITATIS MARIAE CURIE-SKŁODOWSKA

L U B L IN - P O L O N I A

VOL. LXI, 1

SECTIO G

2014

\title{
ANNA PRZYBOROWSKA-KLIMCZAK
}

\section{Funkcje sztuki w twórczości naukowej \\ Profesora Grzegorza Leopolda Seidlera}

The Functions of Art in Scientific Works of Professor Grzegorz Leopold Seidler

W twórczości naukowej Profesora Grzegorza Leopolda Seidlera rozważania na temat roli dzieł sztuki jako nośników idei dotyczą różnych epok historycznych i różnych form wyrazu artystycznego. W swoich pracach zwracał uwagę zarówno na zawarty w dziełach sztuki bezpośredni przekaz, jak i ich sens przenośny - często wyrażany za pomocą symboli i alegorii. Podkreślał też, iż w różnych obiektach kulturalnych twórcy wyrażali wiodące idee epoki historycznej, w której powstawały ich dzieła ${ }^{1}$. Oprócz pierwotnych funkcji sztuki, które odnoszą się do jej oddziaływania na odbiorców z czasów jej tworzenia, pełni ona także funkcje wtórne wobec późniejszych pokoleń. Interesujące rozważania Profesora Seidlera dotyczą sztuki antycznej, średniowiecznej, renesansowej i oświeceniowej.

Wiodącą ideą odzwierciedloną w sztuce antycznej była idea harmonii. Profesor G.L. Seidler stwierdził, że „Dla myśliciela antyku świat wydawał się uporządkowaną jednością, w której rozumna regularność (logos) wyznaczała każdemu elementowi miejsce i funkcję warunkujące spójność całości”’ Wyrazem antycznej idei harmonii były dla autora Rozważań rzeźby Fidiasza ${ }^{3}$. Obecność tej idei w sztuce epoki starożytności ukazał też G.L. Seidler na przykładzie popiersia Glowa Apollina Belwederskiego, wyrzeźbionego w IV wieku p.n.e. przez Praksytelesa. Rzeźba ta, jego zdaniem, była wytworem świata nasyconego światłem, ufnością i wiarą we własne możliwości. Bogowie antyczni przekazywali bowiem ludziom zasady rozumnego działania i uczyli ich reguł harmonii. W celu zapre-

\footnotetext{
${ }^{1}$ G.L. Seidler, W poszukiwaniu naczelnej idei, [w:] Rozważania, Toruń 2002, s. 24-25.

${ }^{2}$ Idem, Z zagadnień filozofii prawa, Lublin 1978, s. 58.

${ }^{3}$ Idem, W poszukiwaniu ..., s. 45.
} 
zentowania kontrastu w sposobach ukazywania różnych idei i emocji tę antyczną rzeźbę zestawił Profesor G.L. Seidler z afrykańską maską, która powstała w świecie „ciemnych sił i strachu”4. Na wyrzeźbionej przez artystę twarzy rysuje się lęk przed nieznanymi siłami wpływającymi na ludzkie losy.

W sztuce średniowiecza funkcję idei wiodącej spełniała idea hierarchii. Jej wyrazem były zdaniem Profesora G.L. Seidlera strzeliste tumy gotyckie ${ }^{5}$. Szczególną wartość jako nośniki idei miały dzieła sztuki sakralnej umieszczone w romańskich i gotyckich kościołach. Przemawiały one do ówczesnego człowieka, zwykle nieznającego pisma, za pomocą lapidarnego języka alegorii i symboli. Jako środki artystycznego wyrazu były one wykorzystywane do przekazywania nauki Kościoła, kształtowania wyobrażenia wiernych o tym, co jest dobre, godne pochwały i o tym, co jest grzeszne, zasługujące na potępienie. W wypadku alegorii droga wiodła od idei, która towarzyszyła twórcy, do obrazu, przy czym związek między przedmiotem przedstawionym a ukrytym znaczeniem był konwencjonalnie ustalony. Posłużenie się symbolem było oparte na odwrotnej sekwencji, a ów związek często nie był tak jednoznacznie określony. Jeden obiekt mógł być symbolizowany przez wiele różnych przedmiotów (np. Matkę Boską przedstawiano w postaci krzewu ognistego, cedru libańskiego, lilii, róży, peonii, diamentu, perły). Niekiedy ten sam przedmiot symbolizował różne obiekty lub wartości: skrzydlaty lew był rozumiany jako taki (interpretacja dosłowna), jako symbol św. Marka (interpretacja alegoryczna), jako symbol siły (interpretacja moralna) lub jako symbol Chrystusa ukrzyżowanego (interpretacja mistyczna) ${ }^{6}$.

W średniowieczu powstały wspaniałe cykle rzeźb cnót i grzechów, które Profesor G.L. Seidler określał mianem „summy teologicznej” epoki. Została ona zamknięta w kamiennych figurach katedry w Chartres i Notre Dame w Paryżu, a także na kapitelu jednej z kolumn Kościoła Notre-Dame-du Port w Clermont. Na kolumnie w Clermont przedstawiono walkę Miłosierdzia ze Skąpstwem, samobójstwo Gniewu, a także Szczodrobliwość i Miłosierdzie, które triumfują nad Skąpstwem. Nawiązano w ten sposób do poematu Aureliusza Prudencjusza Psychomachia, czyli Walka $w$ duszy, przekładając jego treść na język form plastycznych, bardziej czytelnych dla wiernych?

Podczas studiów, uczestnicząc w seminarium magisterskim Profesora G.L. Seidlera i przygotowując pracę magisterską na temat ideologicznych funkcji sztuki, otrzymałam zadanie zapoznania się z podobnymi cyklami rzeźb znajdującymi się w dwóch zabytkach sakralnej architektury w Polsce: kościele ponorbertańskim pod wezwaniem Św. Trójcy i Panny Marii w Strzelnie oraz w katedrze gnieźnieńskiej ${ }^{8}$.

${ }^{4}$ Idem, Rozważania o wspólnocie europejskiej, [w:] Rozważania, s. 49.

${ }^{5}$ Idem, W poszukiwaniu ..., s. 45.

${ }^{6}$ M. Wallis, Sztuka średniowieczna jako język, „Studia Estetyczne”1965, t. 2, s. 28-29.

${ }^{7}$ Szerzej na ten temat zob. Z. Świechowski, Psychomachia, [w:] Funkcje dzieła sztuki, pod red.

E. Studniarkowej, Warszawa 1972, s. 93-102.

${ }^{8}$ Por. A. Przyborowska, Cnoty i grzechy w obrazkach, „Kamena” 1975, nr 13, s. 6, 12. 
Alegorie cnót i grzechów w Strzelnie pokrywają trzony dwóch kolumn usytuowanych po południowej i północnej stronie nawy głównej. Na każdej z kolumn umieszczono $\mathrm{w}$ trzech strefach, oddzielonych roślinnym ornamentem, osiemnaście rzeźb figuralnych. Na obu kolumnach znajduje się zatem 36 personifikacji, które stanowią bardzo rozbudowany cykl prezentujący pod postaciami ludzkimi pojęcia moralne, nawiązujące do teologicznych spekulacji i scholastycznych klasyfikacji pojęć ${ }^{9}$. Na trzonie kolumny południowej, kojarzonej z dobrem, przedstawiono personifikacje cnót wyobrażone przez postacie kobiece z nimbem nad głową. Na kolumnie północnej, łączonej ze złem i siłami szatana, personifikacje grzechów (przywar) są uosobione przez kobiety i mężczyzn ${ }^{10}$.

$\mathrm{Na}$ kolumnie południowej znajdują się personifikacje: Sprawiedliwości z wagą w dłoni; Roztropności (Mądrości) dzierżącej księgę; Wstrzemięźliwości z szeroko rozwartymi ramionami; Cierpliwości z charakterystycznym napominającym gestem ręki; Pokory, będącej w średniowieczu królową cnót, z rękami skrzyżowanymi na piersiach i pochyloną głową; Wiary trzymającej w rękach dwa krzyże; Radości chrześcijańskiej zbliżającej się do ręki Bożej - manus Dei; Czystości z berłem zakończonym kwiatem lilii. Na reliefie kolumny został przedstawiony chrzest Chrystusa, który był zgodnie z nauką Kościoła źródłem wszelkich cnót.

Na kolumnie południowej wyobrażono alegorie: Gniewu w postaci kobiety szarpiącej swe włosy; Pychy, uważanej za główną przywarę, z dumnie uniesioną głową, zachwycającej się swoim pięknym, długim warkoczem; Obżarstwa - postaci o okrągłych kształtach i pełnej twarzy, zbliżającej łapczywie do ust jakiś przedmiot; Niewiary - z lewą ręką na piersi, w prawej trzymającą odwrócony krzyż; Zawiści - z wężem w dłoni; Nieczystości (Rozpusty) - nagiej kobiety z charakterystycznym gestem Wenus wstydliwej; Krzywoprzysięstwa - zjedną ręką na relikwiarzu i drugą uniesioną do góry, z tym że dłonie zostały użyte odwrotnie niż powinny; Bluźnierstwa - z oszczepem bez ostrza; Swawoli - młodego człowieka z dzwonkiem uniesionym w prawej ręce; Zabójstwa - mężczyzny w rycerskiej tunice $\mathrm{z}$ długim mieczem $\mathrm{w}$ dłoni ${ }^{11}$. W górnej strefie kolumny umieszczono rzeźby trzech osób, które też mają związek z przekazem dotyczącym sfery obyczajności. Przedstawiono tam dwie kobiece postacie ze wspaniałymi warkoczami, które towarzyszą młodzieńcowi w długiej szacie i pelerynce, trzymającemu jakiś przedmiot $w$ rękach. Scena ta nawiązuje zapewne do opowieści opisanej przez Herradę z Landsbergu w słynnym Ogrodzie rozkoszy, w której bogaty kleryk-uwodziciel starał się pozyskać za pomocą darów przychylność młodych nowicjuszek ${ }^{12}$.

Nie wszystkie postacie na kolumnach mogą być zidentyfikowane, ponieważ niektóre rzeźby postaci lub ich atrybutów, zwłaszcza na kolumnie południowej,

\footnotetext{
${ }^{9}$ Z. Świechowski, Sztuka romańska w Polsce, Warszawa 1982, s. 57.

${ }^{10}$ Idem, Strzelno romańskie, [w:] Strzelno romańskie. Zbiór studiów, Strzelno 1972, s. 15.

${ }^{11}$ Ibidem, s. 16-17.

${ }^{12}$ Idem, Sztuka romańska ..., s. 58.
} 
zostały zniszczone. Na program tego najbogatszego w romańskiej sztuce monumentalnej cyklu cnót i grzechów miało wpływ prawdopodobnie też Speculum Virginum (Zwierciadło dziewic) z 1130 roku, w którym w wypowiedzi pielgrzyma rozmawiającego z zakonnicą pojawia się obraz dwóch drzew: prawego - drzewa cnoty i lewego - drzewa grzechu.

Inne treściowo i typologicznie wyobrażenie cnót i grzechów znajduje się na południowym portalu Bazyliki prymasowskiej Wniebowzięcia Najświętszej Maryi Panny w Gnieźnie (Katedrze Gnieźnieńskiej). Tympanon zawiera scenę Sądu Ostatecznego, a cykl moralny obejmujący zestawienie cnót i grzechów przedstawiono na pięciu łukach archiwolty, posługując się symboliką zwierzęcą i personifikacjami. Na kolejnych łukach widnieją: 1) lis i zając, 2) wiewiórka i dzik, 3) mężczyzna $\mathrm{z}$ drapieżnym ptakiem na wyciągniętej ręce i kobieta $\mathrm{z}$ krążkami w dłoniach, 4) osiołek obok łodygi ostu i kozioł, 5) rycerz w hełmie z mieczem w dłoni i tarczą, na której przedstawiony jest lew oraz człowiek z włócznią i tarczą z wyobrażonym na niej sercowatym liściem. Ten sposób przedstawienia cnót i grzechów jest dzisiaj trudniejszy do zinterpretowania. W odczytaniu przenośnego sensu obrazów mogą pomóc średniowieczne traktaty moralizatorskie i encyklopedie zwierzęce, tzw. bestiariusze, w których uświadamiano człowiekowi, że natura jest lustrem ustawionym przed ludźmi, by ułatwić im dojrzenie siebie i Boga. Lis był symbolem Szalbierza lub Kłamcy, a zając wcieleniem Tchórzostwa. Wiewiórka symbolizowała Skąpstwo lub nadmierne zainteresowanie posiadaniem dóbr, a dzik występował w archiwolcie jako Gniew. Osiołek był symbolem lenistwa, a kozioł wyobrażał Rozwiązłość, bowiem na nim najczęściej w pochodzie grzechów jechała Luxuria. Rycerz uzbrojony w miecz i tarczę z lwem był symbolem Męstwa, kobieta z tamburynem w dłoni uosabiała łatwe życie - Lekkomyślność, a człowiek z sercowatym liściem na tarczy stanowił alegorię Miłosierdzia. Te elementy z portalu zostały też przeniesione na gzymsy Katedry i ułożone w różnych zestawach ${ }^{13}$.

Należy zauważyć, że także w późniejszych okresach sztuka sakralna posługiwała się tego rodzaju alegoriami cnót i grzechów. W starym kapitularzu gnieźnieńskiej Katedry na sklepieniu znajdują się pochodzące z połowy XVII wieku malowidła przedstawiające personifikacje trzech cnót teologicznych i czterech kardynalnych. W trzech środkowych kwaterach na sklepieniu namalowano Miłosierdzie przedstawione jako niewiasta z dziećmi, Wiarę z krzyżem i wstęgą, na której znajduje się napis „Credo is unum Deum”, i Nadzieję z kotwicą, na tle morskiego pejzażu. Wokół nich umieszczono personifikacje: Sprawiedliwości z mieczem i wagą, Roztropności ze zwierciadłem i wężem, Umiarkowania nalewającego wodę z dzbana do pucharu i Męstwa z kolumną w dłoni.

Symbole i alegorie w sztuce sakralnej, za pomocą których w obrazowej, lapidarnej formie ukazywano cnoty i grzechy, miały oddziaływać na pobudki ste-

${ }^{13}$ A. Świechowska, Katedra gnieźnieńska, Poznań - Warszawa - Lublin 1970, s. 134-150. 
rujące zachowaniem i miały być na tyle jednoznaczne, by człowiek nie gubił się w domysłach, by kojarzenie było szybkie, pomijające dosłowną treść i by ocena była zgodna z obowiązującym systemem wartości i wiodącą ideą - hierarchii.

Do tej idei nawiązuje też słynny fresk Giotta z początku XIV wieku, przedstawiający Sąd Ostateczny, znajdujący się w kaplicy Scrovegni w Padwie. Chrystus jest otoczony na nim ustawionymi w równych szeregach aniołami i świętymi. Po lewej stronie u stóp Chrystusa znajduje się piekło z postaciami personifikującymi złe siły, skupionymi wokół szatana, do którego prowadzi ognisty strumień. W ten sposób starano się przeciwstawić niebu, będącemu Królestwem Bożym, grzeszny świat doczesny ${ }^{14}$.

Sztuka epoki Odrodzenia miała sławić człowieka i świat. W twórczości artystów renesansu postaci były żywe, wkomponowane w otaczającą je rzeczywistość, dzięki czemu mogły wpływać na kształt realnego świata. Zdaniem Profesora G.L. Seidlera jedno z najsłynniejszych dzieł tej epoki - posąg Dawida, dłuta Michała Anioła, ,jest wspaniałym świadectwem estetycznego odkrycia człowieka, który wyraża sobą klasyczną harmonię ciała, rozumu i ducha, patrząc jednocześnie $\mathrm{z}$ ufnością $\mathrm{w}$ przyszłość" ${ }^{15}$. Stanowi on zatem symbol antropocentryzmu i jednocześnie wyraz realistycznego uniwersalizmu, budząc skojarzenie „z wielką orkiestrą symfoniczną zespalającą w jedną potężną melodię dźwięki różnych instrumentów"16.

Naczelnymi ideami Oświecenia były natura i rozum. Natura miała wyrażać dobro i normalność, a rozum miał pomagać w poznaniu istoty wszystkich zjawisk, Dzięki niemu powinny zniknąć wszelkie przesądy, irracjonalne wierzenia i mity ${ }^{17}$. Oryginalnym spojrzeniem na racjonalizm epoki Oświecenia były sceny przedstawione na rycinach Francisco Jose Goi. Autor słynnych dzieł, m.in. obrazów Maja naga i Maja ubrana, cyklu Okropności wojny i pełnego dramatyzmu obrazu Rozstrzelanie powstańców madryckich, 3 maja 1808 roku namalował osiem rycin ilustrujących główne idee Oświecenia.

Pierwsza rycina przedstawia pogrążonego we śnie inteligenta, ubranego w modny strój, wokół którego unoszą się sowy uosabiające mądrość, a także tajemnicze latające stwory. Obraz zatytułowany Uśpiony rozum budzi demony miał wyrażać myśl, że gdy rozum nie działa, to świat wypełnia się siłami zła, demonami.

Na drugiej rycinie, będącej prawdopodobnie autoportretem Goi, mężczyzna w stroju arystokraty siedzi z zamkniętymi oczyma, opierając się o stół, a obok niego znajduje się stos książek i narzędzia służące do grawerowania. Z głowy śpiącego emanuje światło, które rozprasza ciemności. Widoczne są też twarze innych postaci, co oznacza, że artysta nie jest osamotniony w widzeniu świata.

${ }^{14}$ G.L. Seidler, W poszukiwaniu..., s. 30.

${ }^{15}$ Ibidem, s. 34.

${ }^{16}$ Ibidem, s. 45.

${ }^{17}$ Idem, Rozważania o racjonalizmie, [w:] Rozważania, s. 166. 
$\mathrm{Na}$ trzeciej rycinie lewa strona pozostała pusta, a w drugiej części obrazu nad śpiącą postacią, pozbawioną akcesoriów przedstawionych na pierwszej rycinie, został umieszczony wielki nietoperz. Intencje autora zostały zawarte w umieszczonym pod ryciną napisie: „Autor marzy, mając na uwadze jeden cel, aby usunąć szkodliwe i powszechnie utrzymujące się fałszywe idee oraz aby rycinami Caprichos dowieść solidnej prawdy".

Czwartą rycinę stanowi autoportret Goi z profilu, przy czym na jego twarzy maluje się sceptycyzm lub sarkazm. Artysta ubrany jest w strój mieszczanina, poprzez który chce zademonstrować pewien dystans wobec postawy arystokracji.

Piąta rycina jest uznawana za najbardziej rewolucyjną pod względem zawartego w niej przekazu. Przedstawiono na niej osły, które umieszczono na karkach ludzi. Zwierzęta mają wyobrażać nielubiane elity rządzące dźwigane przez uciskanych poddanych.

Na szóstej rycinie artysta namalował małpę grającą na gitarze. W ten sposób F.J. Goya chciał ukazać, że słabych artystów charakteryzuje zły smak i naganne obyczaje. Obok znajduje się osioł uosabiający władzę oraz pochlebcy oklaskujący występy małpy.

Siódma rycina przedstawia Don Kichota, żyjącego w świecie ułudy, oderwanego od rzeczywistości, nad którego głową unoszą się głowy księży i monarchów.

$\mathrm{Na}$ ósmej rycinie zatytułowanej Odmienne prawa dla ludzi został narysowany olbrzymi słoń, będący alegorią ludu, który przytłacza swą wielkością dostojników państwowych.

Cykl rycin ma za pomocą karykatur i symboli piętnować ludzkie błędy i przywary, nawiązując do dawnych cykli wad i cnót ${ }^{18}$.

W kilku swoich pracach Prof. G.L. Seidler zajął się twórczością artystyczną czasów rewolucji francuskiej, którą przywódcy i ideolodzy rewolucji wykorzystywali w celu wychowania nowego człowieka ${ }^{19}$. Problemy etyczne odgrywały w tych czasach istotną rolę, a całkowita przebudowa świadomości społecznej była traktowana jako podstawowy warunek wprowadzania nowego ustroju. Za pomocą szerokiej propagandy rewolucyjnych ideałów dążono do uzyskania jedności myślenia i działania całego społeczeństwa, które miało na ziemi zbudować wymarzoną republikę cnót. Jakobini, uznając kult rozumu, traktowali go jako siłę zdolną do stworzenia sprawiedliwego ustroju, bowiem rozum uwolniony od wszelkich krępujących go więzów był też przez nich uznawany za najwyższego prawodawcę, niezależnego od autorytetów ziemskich i boskich.

Podczas rewolucji korzystano też z nowej symboliki. Szerokie jej stosowanie w sztuce, podczas różnych wystąpień, masowych pochodów i festiwali ludowych

${ }^{18}$ Ibidem, s. 168-178.

${ }^{19}$ Idem, The Pathos of the Jacobin Revolution, „Annales UMCS. Sectio G” 1976, Vol. XXIII, 1, s. 1-25; Idem, W nurcie Oświecenia, Lublin 1984, s. 59-96; Idem, Rozważania, s. 180-249. Por. też: Idem, Sztuka orężem ideologii jakobińskiej, „Kamena” 1977, nr 24, s. 4-5 i nr 25, s. 4-5. 
spowodowało, że symbole i alegorie były na ogół jednoznacznie odczytywane. Do powszechnie wykorzystywanych symboli tego okresu należały: poziomica oznaczająca równość, czapka frygijska kojarzona z wolnością, pika symbolizująca broń wolnych ludzi, maczuga przedstawiająca wolę powszechną. W symbolicznym języku często pojawiały się rózgi liktorskie obrazujące rewolucyjną solidarność, drzewo dębowe, które miało oznaczać odrodzenie cnót obywatelskich i oko opatrzności symbolizujące czujność rewolucyjną. Najważniejsze idee rewolucji: wolność, równość i braterstwo przedstawiano w postaci trzech kobiet zaopatrzonych w odpowiednie symbole. Za pomocą personifikacji ukazywano też m.in.: rozum, naturę, prawdę, zwycięstwo i sprawiedliwość ${ }^{20}$.

Wielu twórców sztuki zaangażowało się w sprawy rewolucji, zarówno podejmując działalność polityczną, jak i wyrażając poparcie dla idei rewolucyjnych w swoich dziełach ${ }^{21}$. Patos rewolucji jakobińskiej jest szczególnie widoczny w twórczości Jacquesa Louisa Davida. Profesor G.L. Seidler posłużył się przykładami trzech wybitnych dzieł, które zostały wystawione w tzw. paryskim Salonie $^{22}$. Tym mianem określano wystawy malarstwa organizowane w Paryżu co dwa lata pod auspicjami Królewskiej Akademii Malarstwa i Rzeźby. Pierwszy z tych obrazów Przysięga Horacjuszów znalazł się na wystawie w 1785 roku. Malarz przedstawił na nim trzech wojowników rzymskich z uniesionymi prawymi rękoma, przysięgających na miecze trzymane przez ich ojca, że będą walczyli za Ojczyznę na śmierć i życie. Drugi obraz, wystawiony w 1787 roku, był zatytułowany Śmierć Sokratesa. Przedstawiono na nim mędrca otoczonego uczniami, który decyduje się na śmierć w imię głoszonej przez siebie prawdy. Trzeci obraz, zatytułowany Liktorowie niosacy na marach zwłoki synów Brutusa, został wystawiony w 1789 roku, już po zburzeniu Bastylii. Dawid namalował na nim konsula Brutusa, do którego domu Liktorowie wnoszą ciała synów, którzy zostali przez niego skazani na śmierć za zdradę Republiki.

Innym dziełem Dawida, które Profesor G.L. Seidler określił jako „prawdziwą rewolucyjną pietę", był obraz Śmierć Lepeletiera ${ }^{23}$. Na obrazie tym Michał Lepeletier, popularny wśród ludu członek Konwentu, zamordowany przez rojalistę w styczniu 1793 roku, został przedstawiony w sposób, w jaki w sztuce religijnej prezentowano martwego Zbawiciela Jezusa Chrystusa. Nad ciałem Lepeletiera artysta namalował skrwawiony miecz, przecinający kartkę papieru, na której umieszczono napis: „Głosuję za śmiercią tyrana”. Obraz był wystawiony w sali obrad Konwentu, ale nie przetrwał do obecnych czasów i znany jest z zachowanych dwóch reprodukcji i opisów ${ }^{24}$.

\footnotetext{
${ }^{20}$ Idem, W nurcie Oświecenia, s. 74-76.

${ }^{21}$ Ibidem, s. 95.

${ }^{22}$ Idem, The Pathos..., s. 2-3.

${ }^{23}$ Idem, W nurcie Oświecenia ..., s. 80.

${ }^{24}$ Ibidem, s. 255.
} 
Ideolodzy epoki Oświecenia żądali od twórczości artystycznej społecznego zaangażowania, pragnęli, by sztuka wychowywała i umoralniała. Odnosząc się do funkcji sztuki w wychowaniu człowieka, wskazywano, że może ona odgrywać trzy zasadnicze role: poznawczą, kompensacyjną i aktywizującą ${ }^{25}$. Rolę poznawczą pełni sztuka, ponieważ przedstawia obrazy dotyczące aktualnej rzeczywistości społecznej i jej dalszego rozwoju. Artystyczna wizja powstaje jako swoista synteza treści indywidualnych i ogólnych, dokonana w drodze świadomego wyboru i zestawienia określonych cech. Rola kompensacyjna polega na tym, że sztuka, przenosząc człowieka w inny świat, pozwala mu oderwać się od rzeczywistości, niekiedy wynagradza jej braki, a następnie oddaje go tej rzeczywistości, ale już jako człowieka mądrzejszego, silniejszego i szczęśliwszego. Aktywizująca rola sztuki wyraża się w pobudzaniu do działań. Sztuka bowiem wyraża i pogłębia niepokoje, pobudza do myślenia i szukania własnych rozwiązań.

Z tymi trzema poziomami wychowawczego oddziaływania sztuki łączono trzy wielkie mity: o Filoktecie (rola poznawcza), o Orfeuszu (rola kompensacyjna) i o Prometeuszu (funkcja aktywizująca). W micie o Filoktecie sztuka jest rzeczą niezbędną, potrzebną, by zwyciężać i budować. Mit o Orfeuszu odwołuje się do kojącej i orzeźwiającej mocy muzyki, poezji i innych form sztuki. Orfeusz przywracał ludziom poczucie równowagi i harmonii z otoczeniem. Trzeci mit opowiada o wstrząsie i o budzeniu ludzkiego sumienia. Walka Prometeusza kończy się tragicznie, ale konflikt między rzeczywistością a własnymi możliwościami nie ustaje. Inwersją motywu Filokteta jest postawa artysty zapatrzonego w siebie, odciętego od rzeczywistości, mitu Orfeusza - fałsz estetyczny, polegający na aprobowaniu sztuki pozbawionej autentycznej wartości, a mitu Prometeusza - usypianie ludzkich sumień poprzez zamazywanie konfliktów i sprzeczności ${ }^{26}$.

We wszystkich epokach historycznych sztuka miała nie tylko kształtować estetyczną wrażliwość, ale sięgając do różnych środków wyrazu, powinna kształtować człowieka i jego stosunek do świata, do innych ludzi i samego siebie. Kontakt ze sztuką wymaga bowiem osobistego zaangażowania, zharmonizowania dyspozycji poznawczych, uczuć i wyobraźni. Oddziaływanie symboli w sztuce odznacza się pewną specyfiką. Idee niejako roztapiają się w znakach, a symbole stanowią swoisty ekwiwalent określonej treści, pełniąc funkcje zastępników semantycznych i asocjacyjnych ${ }^{27}$. Dzieła sztuki zwykle nie mają bytu samoistnego, bowiem często powstają jako element współpracy między artystą a odbiorcami tych dzieł. Między artystą, jego twórczością i społeczeństwem kształtuje się szczególna więź, dzięki której idee wyrażone w dziełach sztuki mogą docierać do odbiorców szybciej i bardziej wszechstronnie niż te zawarte w doktrynach i ma-

${ }^{25}$ Por. B. Suchodolski, Wspótczesne problemy wychowania estetycznego, [w:] Wychowanie przez sztuke, pod red. I. Wojnar, s. 27-34.

${ }^{26}$ S. Morawski, Trojaka funkcja wychowawcza, „Estetyka” 1963, t. 4, s. 30-35.

${ }^{27}$ Stownik terminologiczny sztuk pięknych, pod red. S. Kozakiewicza, Warszawa 1969, s. 334. 
nifestach ideologicznych. Myśl tę Profesor G.L. Seidler wyraził w następujących słowach: „Mężowie stanu, pisarze, filozofowie i inni intelektualiści mogą wypowiadać wzniosłe myśli. Wojny mogą być rozmaicie naświetlane, ale dzieła sztuki - jeśli istnieją - przemawiają do nas bezpośrednio całą swą siłą"28.

\section{SUMMARY}

In his works, Professor G.L. Seidler emphasized the role of art as a catalyst for leading ideas of historical eras while those works were created. The ancient art reflected the idea of harmony, particularly evident in the sculptures of Phidias. In the Middle Ages the idea of hierarchy was the leading one. It was expressed in the great sacred works of Romanesque and Gothic art. Fixed in stone allegories of virtues and sins were also adressed to the faithful of this era. One of the most well-known sets are personifications of 18 virtues and 18 sins placed on two columns in Norbertine Church of the Holy Trinity and the Virgin Mary in Strzelno. The aim of the art of the Renaissance was the glorification of man and the world. The symbol of the Renaissance anthropocentrism is the statue of David, sculpted by Michelangelo. Professor G.L. Seidler has also devoted a lot of his attention to the art of age of Enlightenment, which leading ideas were nature and reason. These ideas were expressed in Francisco Jose Goya's engravings. The pathos of the Jacobin revolution is apparent in the works of Jacques Louis David, and especially in three of his paintings exhibited in the so-called "The Paris Salon" between 1785-1789.

${ }^{28}$ G.L. Seidler, Rozważania o wspólnocie..., s. 49. 